\title{
Ground Improvement of Tank Foundations in the Middle East
}

\author{
Babak Hamidi $^{1(\bowtie)}$ and Serge Varaksin ${ }^{2}$ \\ 1 ISSMGE TC-211 Member, Perth, Australia \\ babakhamidi@hotmail.com \\ 2 Apageo, ISSMGE TC-211 Co-chairman, Paris, France
}

\begin{abstract}
Although tank construction is well advanced in the Middle East, not all tanks are located on suitable grounds, and many require the implementation of specific foundation measures to ensure that design specifications are satisfied. While ground improvement of tank foundations in the region has a proven track record that dates back to the 1980 s, and can potentially be the most appropriate solution for many tanks, it is the authors' experience that occasionally the projects' settlement requirements appear to have been influenced by building specifications that have not been developed for the purpose. Consequently and unnecessarily, more expensive solutions with longer construction schedules may have to be adopted that will not bring any additional benefits to the foundation solution. This paper initially reviews settlement criteria of a number of internationally recognized standards and then presents a number of case studies of tank foundation improvement by dynamic compaction and quality control by Menard pressuremeter tests.
\end{abstract}

\section{Introduction}

Industrial scale tanks are usually large and heavily loaded structures that are used to store fluids and must remain in uninterrupted service due to their commercial value and social importance. For example, any disruption in the supply of potable water or fuel due to a tank becoming temporarily non-operational will immediately attract public attention and can lead to social anxiety or unrest if the matter is not addressed and resolved rapidly.

With consideration that tanks are relatively thin structures, unforeseen and unaccounted ground deformations can impede the performance of the tanks, and ultimately lead to tank failure. Hence, implementation of specific foundation techniques has become common practice when in-situ ground conditions are not able to provide foundations with the required bearing or deformation limitations.

Ground improvement in general and dynamic compaction, in particular, have been used extensively for tank foundation improvement since the early 1970s. Dynamic compaction was first used for the improvement of a Petro France tank in Villeneuve La Garenne in 1972. The same technique was also used for the first time respectively for oil tanks in Africa (Congo) in 1973, in Asia (Japan) in 1975, in North America (Los Angles) in 1977, and in South America (La Plata, Argentina) in 1980. However, it was only not until 1988 that dynamic compaction and replacement were first used in the Middle East 
for the treatment of Iraqi Sate Company for Oil Project's tank farm in Yanbu, Saudi Arabia. Among other structures and infrastructures, this project included 10 large crude oil storage tanks, each with diameters and heights that were respectively $110.8 \mathrm{~m}$ and $20 \mathrm{~m}$. Two smaller fuel storage tanks were also treated in the same manner.

Today, hundreds of tank foundations have been treated using ground improvement throughout the world, many of which have been documented through conference proceedings or journal publications. Some interesting publications include Cognon et al. (1983); Hendy and Muir (1997); Ihm and Masse (2001); Hamidi and Jullienne (2007); Buschmeier et al. (2012); Debats et al. (2013) and Hamidi et al. (2016).

\section{Tank Settlements}

Unlike buildings that are basically hollow structures, tanks are heavily loaded thin-shelled structures that exert large loads to large foundations. Hence, tank owners are generally and rightfully very sensitive to foundation movements as any disturbance in the performance of tanks can have significant commercial or social impacts. However, it is the authors' experience that when decision-making engineers have a civil or building background or are not sufficiently familiar with existing research and current tank codes of practices, they tend to stipulate settlement criteria requirements that are unrealistically and unnecessarily onerous and more appropriate and applicable to buildings rather than tanks. The authors have even been involved in discussions where the settlement requirement was zero, which is physically meaningless.

In reality, the impact of ground movement on tanks has been well researched since years ago (Marr et al. 1982; D’Orazio and Duncan 1987), and contrary to most structures whose global performances due to full loadings are only assessable after completion of construction and during utilization phase, tanks are typically subjected to a full-scale hydro test loading before becoming operational.

Internationally recognized standards such as American Petroleum Institute (API), American Concrete Institute (ACI), and Engineering Equipment and Materials Users Association (EEMUA) provide guidelines and minimum requirements for tank foundation deformations. Based on internal knowledge and know-how, other organizations such as Mobil (1990) have also developed their own specifications.

\subsection{Types of Tank Settlement}

Tank settlements can be envisaged to be uniform, rigid body tilting or planar tilting, and out-of-plane settlement or differential settlement. These types of movements can result in various forms of failure, of which the ones that are most concerning are the distortion of the shell, rupture of the shell or bottom plate or shell-bottom plate connection (Marr et al. 1982).

\section{Uniform Settlement}

The uniform settlement of a tank is shown in Fig. 1. Most standards do not appear to be overly sensitive to this type of settlement, but occasionally draw attention to its effect 
on the piping, which can be resolved by using flexible connections or periodically repositioning the pipe supports.

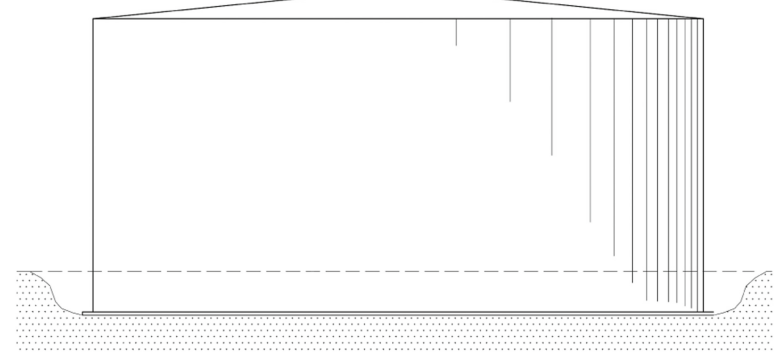

Fig. 1. Uniform settlement

API 620 (American Petroleum Institute 2002) that is applicable to the design and construction of large, welded, low-pressure storage tanks does not stipulate limits on settlement, but notes that uniformity of support and avoidance of excessive settlement are much more important for tanks that have formed bottom plates than they are in the case of flat-bottom, vertical storage tanks.

API 625 (American Petroleum Institute 2010) that is used for refrigerated liquefied gas storage tanks systems simply notes that the amount of acceptable uniform settlement depends on piping and structural connections between the tank system and adjacent structures.

API 650 (American Petroleum Institute 2007) that is utilized for welded tanks also does not limit this type of settlement but states that total settlement must not strain connecting piping or produce gauging inaccuracies, and that settlement should not continue to a point at which the tank bottom is below the surrounding ground surface. This standard further specifies that estimated settlement should be within the acceptable tolerances for the tank shell and bottom, and adds that if a large settlement is expected, then the tank bottom elevation should be raised so that the final elevation above grade will be a minimum of $150 \mathrm{~mm}$ after settlement.

API 653 (American Petroleum Institute 2003) that is applicable to tank inspection, repair, alteration, and reconstruction notes that excessive foundation settlement of storage tanks can affect the integrity of tank shells and bottoms, and adds that this type of settlement could affect tank nozzles that have piping attached to them. While this standard does not limit total settlements, it states that for existing tanks with histories of successful services, it may be possible to accept greater settlements and distortions of the foundation from a true plane than new tank construction standards allow.

ACI 376 (American Concrete Institute 2010) that has been developed for the design and construction of concrete structures for the containment of refrigerated liquefied gasses permits uniform settlement of concrete shallow foundations provided that the other provisions of the standard are met, and the connecting piping system accommodates the settlement. 


\section{Rigid Body Tilting}

Figure 2 shows rigid body tilting or planar tilting. This form of settlement of the shell reduces freeboard, alters the shape of the fluid surface, and places additional stresses in the shell (Marr et al. 1982). Marr et al. show that a planar tilt that is 5\% of the tank diameter will increase the hoop stress at the bottom of the shell by $10 \%$. While they assess that failure of the shell from planar tilt alone seems unlikely, and note that this type of tilting appears to have no detrimental consequence to the structural integrity of the bottom plate, Marr et al. propose limits to avoid spilling oil from floating roofs or exceeding the tolerance of the floating roof by stressing and deforming the shell.

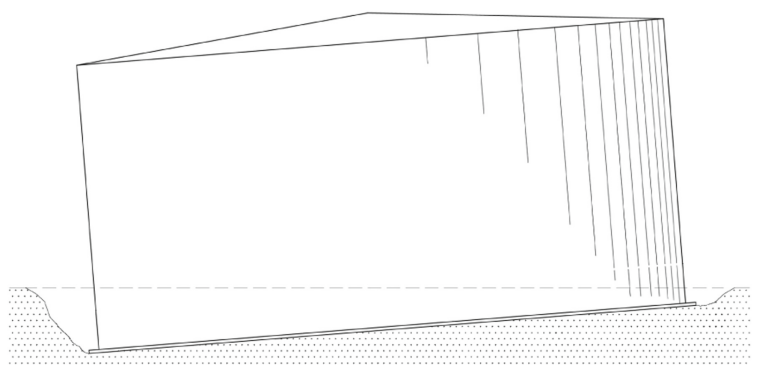

Fig. 2. Rigid body or planar tilting

While API 620 does not stipulate limits to planar tilting of steel tanks, API 625 allows variations from the settlement limits that it specifies provided that they are accounted for in the design of the tank system and interconnecting components, which in the authors' opinion, is a very rational approach that should be considered as good practice. API comments that while large tanks may be able to accommodate significant tilting without damage, other components usually require lower values of tilt, and thus limits its predicted value to Eq. 1:

$$
G T<25.4 \alpha \frac{D}{H}
$$

$G T=$ global (rigid body) tilt settlement, in $\mathrm{mm}$

$\alpha=5$, but often restricted to lesser values as a result of the same issues that are of concern for uniform settlement.

$D=$ tank diameter

$H=$ tank height.

ACI 376 limits differential settlement or planar tilting to $1 / 500$.

Out of Plane Settlement

Dishing of the tank bottom, which is shown in Fig. 3 is the most commonly envisaged form of out-of-plane settlement. However, non-planar settlements do not necessarily 


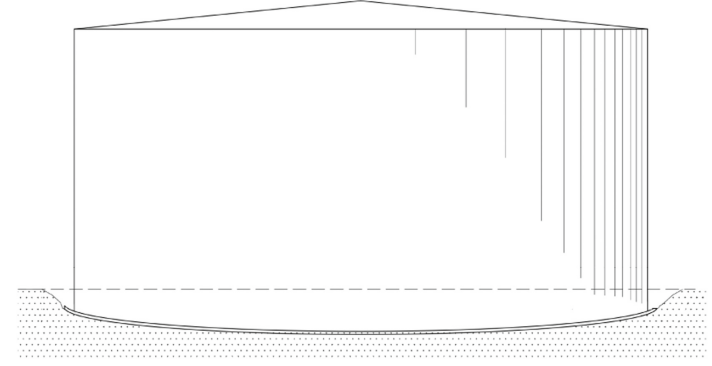

Fig. 3. Out of plane settlement in the form of tank bottom dishing

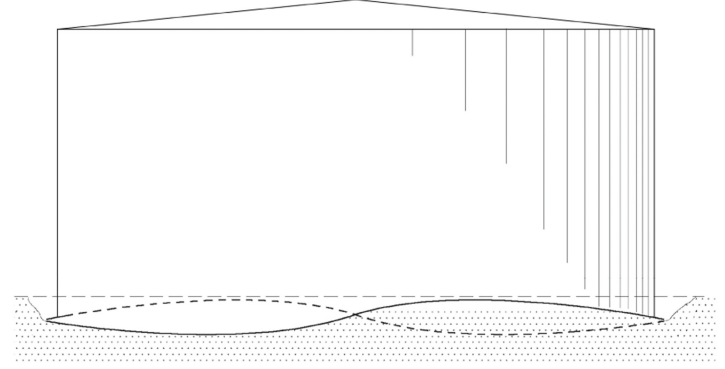

Fig. 4. Out of plane settlement in the form of warping

have to be from the center of the tank to the shell and can be localized at the connection of the shell to the bottom plate in the form of a localized bulge or warping, which is shown in Fig. 4.

Out-of-plane, non-planar or differential settlement may radially distort or overstress the shell, which can result in the malfunction of a floating roof. Overstressing can also rupture the shell. Dish-shaped settlements and localized depressions in the bottom plates of tanks will overstress the plate and welds. Alternatively, the shell-bottom plate connection may rupture when the shell bridges over a soft spot, but the bottom plate settles with it (Marr et al. 1982).

API 620 does specify any limits for non-planar settlement of steel tanks. However, API 625 limits predicted differential settlements between the edge of the tank and the center $(D S)$, and around the periphery of the tank (TS) respectively to Eqs. 2 and 3.

$$
D S<R / 240
$$

$R=$ tank radius

$$
T S<1 / 1000
$$


API 653 seems to be more tolerant on differential settlement of existing tanks. Based on the publication of Marr et al. (1982) this standard uses Eq. 4 to calculate the maximum permissible out of plane deflection of the shell:

$$
|S| \leq \frac{11 L^{2} Y}{2 E H}
$$

$S=$ deflection

$L=$ arc length between two points

$Y=$ yield strength

$E=$ Young's modulus.

The units of $L, S$, and $Y$ are the same as are the units of $E$ and $Y$.

API 653 limits the permissible bulge or depression of the tank bottom to:

$$
B_{B} \leq 30.8 R
$$

$B_{B}=$ maximum height of bulge or depth of local depression, in $\mathrm{mm}$

$R=$ radius of inscribed circle in bulged area or local depression, in $\mathrm{m}$.

ACI 376 limits dishing along a radial line from the outer perimeter to the tank center to $10 \mathrm{~mm}$ drop of $1 / 300$, and notes that restricting the dishing settlement to $1 / 300$ maintains the bending curvatures within acceptable limits so that insulation materials are not damaged. Specialists have commented on the $10 \mathrm{~mm}$ criterion as being unclear and too conservative. ACI Committee's response is that it is agreed that $10 \mathrm{~mm}$ criterion should be deleted (ACI Committee 376 2010).

ACI also limits footing settlement around the perimeter of the tank to the lesser of $1 / 500$ and the maximum settlement limit calculated for the uniform (planar) tilting of the tank.

\section{Case Histories of Dynamic Compaction Application to Tanks in the Middle East}

\subsection{LNG Tanks in Ras Laffan, Qatar}

\section{Introduction and Ground Conditions}

LNG Tanks T-4, T5, and T-6 are located within the reclaimed port area of Ras Laffan in Qatar, and the foundations of all three have been treated using dynamic compaction. Although there were some differences in the specifications and construction procedures of these tanks, as the ground improvement methodology of all three were very similar, only the process implemented during the ground improvement works of Tank T-6 (Hamidi and Jullienne 2007) will be reviewed. 
Tank T-6's capacity is $140,000 \mathrm{~m}^{3}$, and its inner steel tank diameter and height are respectively $74.3 \mathrm{~m}$ and $35 \mathrm{~m}$. The outer concrete shell has an internal diameter of $76.3 \mathrm{~m}$. The LNG storage level is $34 \mathrm{~m}$, and the maximum hydrostatic test level was specified to be $19.98 \mathrm{~m}$.

The tank's site was fairly flat. Based on boreholes that were as deep as $80 \mathrm{~m}$, cross-hole tests to depths of $45 \mathrm{~m}$, cone penetration tests (CPT) within the soil layers, Menard Pressuremeter Tests (PMT), and laboratory tests on recovered samples, the ground at the tank's location was understood to consist of a superficial well graded fine to coarse calcareous sand layer that was mixed with angular gravel. This layer's fines content was less than $30 \%$. At localized areas, the sand was slightly cemented at the base of the layer. Weathered limestone, approximately $3.5 \mathrm{~m}$ thick, was encountered at about $4 \mathrm{~m}$ below ground level, followed by $3 \mathrm{~m}$ of upper limestone, $12 \mathrm{~m}$ of lower limestone, $30 \mathrm{~m}$ of calcareous siltstone, and at least $90 \mathrm{~m}$ of calcareous sandstone down to end of boring. Cavities were detected in the siltstone and sandstone layers, and groundwater was encountered approximately $2 \mathrm{~m}$ below ground level.

Acceptance criteria for the project were defined to be:

- Maximum settlement at the tank's perimeter: $80 \mathrm{~mm}$

- Maximum deviation from any planar tilt of the foundation between any two points: 1/700 (25 mm differential settlement over any $17.5 \mathrm{~m}$ horizontal distance).

Using the specification's differential settlement criterion over a distance of $40 \mathrm{~m}$ between the center and edge of the tank measured from the concreting of the joint at the wall to the mat, it can be calculated that the center of the tank was able to settle an additional $57 \mathrm{~mm}$ or a total of $137 \mathrm{~mm}$.

Hamidi and Jullienne (2007) have tabulated the design values for the thicknesses, densities, Young moduli, Poisson ratios, cohesion, and internal friction angle of each layer. Initial calculations suggested that the ground would not be able to satisfy the specifications, and ground improvement was considered as a viable solution of interest.

\section{Foundation Solution: Dynamic Compaction with a Shear Ring Trench}

The ground improvement works for satisfying the design basis were awarded to a specialist contractor who had proposed the application of dynamic compaction. As shown in Fig. 5, in this scheme a shear ring trench was constructed by excavating a

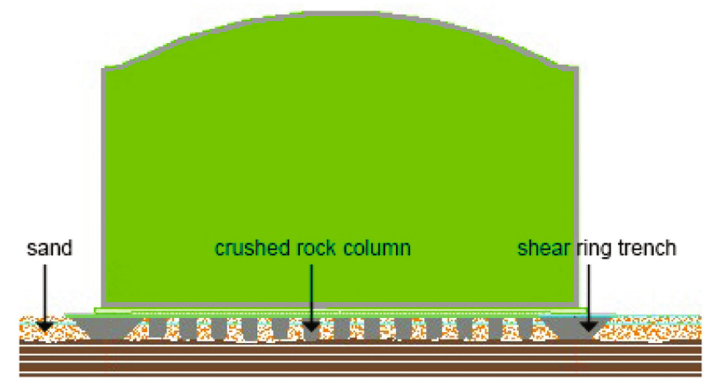

Fig. 5. Schematic cross section of tank and ground treatment scheme 
$3.5 \mathrm{~m}$ deep trench around the tank and simultaneously backfilling it with crushed stone. The trench had a trapezoidal cross-section, with the top and bottom bases being respectively $12 \mathrm{~m}$ and $5 \mathrm{~m}$.

The crushed stone used was up to $200 \mathrm{~mm}$ in diameter, the Los Angles abrasion of aggregate coefficient was less than 35 , and fines content was less than $5 \%$.

Similar to dynamic replacement that is typically performed by backfilling the impact craters with crushed stone and applying additional blows to enlarge, deepen and compact the granular inclusions, in this project the prints were initially excavated and backfilled with crushed stone to provide larger granular columns with better mechanical properties than compacted sand. The trench was then dynamically compacted to increase local bearing capacity, resistance against local shear failure under the tank's shell and to reduce edge settlements.

\section{Testing and Verification}

Analysis of settlements was undertaken using finite element analysis software with consideration of the tank's construction methodology; i.e. the construction of the perimeter ring beam and tank wall to approximately $38 \mathrm{~m}$ height, construction of the central portion of the mat, construction of the joint between the ring beam and the mat, construction of the steel cupola, construction of the inner tank, construction of the outer tank wall haunch and roof, hydro testing, and operation of the tank.

It was calculated that the maximum settlement of the tank would occur in its center during the hydro test $(57.5 \mathrm{~mm})$, but the maximum differential settlement $(0.83 / 700)$ would take place after construction of the ring beam and tank wall and prior to the placement of concrete at the joint.

Field tests were performed during calibration of dynamic compaction parameters and after treatment. PMTs were carried out at 25 locations, of which 3 were during the calibration phase and the remaining were after the treatment. The tests were performed at every one meter before reaching bedrock. 14 plate load tests were also carried out on circular plates with diameters of $1 \mathrm{~m}$, of which 2 were performed during the calibration phase.

Testing and interpretation of the results indicated that the average moduli of deformation in the dynamic replacement columns within the tank, compacted sand, and ring trench were respectively 75.2 $\mathrm{MPa}, 36.9 \mathrm{MPa}$, and 70.1 $\mathrm{MPa}$.

While maximum vertical settlement at the end of construction was calculated to be $31.7 \mathrm{~mm}$ under the tank wall, surveying of 18 plates installed on the wall indicated that measured total settlement during the hydro test were from 4 to $10 \mathrm{~mm}$, and differential settlement between any two adjacent points was in the range of null to $3 \mathrm{~mm}$.

\subsection{STP Tanks in Palm Jumeira, Dubai}

\section{Introduction and Ground Conditions}

A sewerage treatment plant (STP) tank has been built on each of the two outer crescent islands of Palm Jumeira in Dubai, UAE. Due to the similarity of the ground improvement technique applied at these two sites, only the first plant (Lot A-A) will be reviewed in this paper; however, Hamidi et al. (2011) and Hamidi and Varaksin (2015) 
have described the ground improvement works of both tanks (Lots A-A and G-G) in detail.

Palm Jumeira is a reclaimed group of man-made islands that consists of a trunk, a crown with 17 fronds, three surrounding crescent islands that form a breakwater and two smaller islands that are in the shape of the logo of project's developer. The main body of the development consists of calcareous sand that was dredged from the Persian Gulf. When possible, sand was discharged from the bottom of the hulls of trailing suction hopper dredgers, but when the water was shallow, the dredgers sprayed the sand and water mixture onto the reclamation by rainbow discharge.

Due to the low strength and high compressibility of the soil, ground improvement by vibro compaction was carried out almost throughout the reclamation. Additionally, piles were also installed to support the heavily loaded structures. The two STP tanks are the only heavily loaded structures of the development that are only found on ground that has been improved by dynamic compaction and dynamic surcharging.

The STP lots are located on the tips of the outer crescents. Each plant includes one reinforced concrete tank with a diameter of $35.1 \mathrm{~m}$, which was envisaged to be subjected to a total uniform load of $120 \mathrm{kPa}$.

As part of the general geotechnical investigation of the reclamation, two SPT (standard penetration test) boreholes and two CPTs (cone penetration test) were performed near the location of Tank A-A. The boreholes indicated that the upper crust of the soil was generally very dense with SPT blow counts, $N$, reaching 28 . The deeper layers of soil were less dense, with minimum $N$ in the upper $8 \mathrm{~m}$ of soil being as low as 5 . The soil then appeared to become denser with a minimum $N$ of 18 and exceeding 50 at the depth of $13 \mathrm{~m}$. The fines content of the soil in these two boreholes were from 2 to $10 \%$ in the upper $13 \mathrm{~m}$ of soil but increased to $22 \%$ at the depth of $14.5 \mathrm{~m}$. Ground level was at $+4 \mathrm{~m} \mathrm{RL}$ (reduced level) and groundwater was at the depth of about $3 \mathrm{~m}$. CPT cone resistance, $q_{c}$, in the upper $2 \mathrm{~m}$ of sand was as high as $25 \mathrm{MPa}$. The soil then became loose with $q_{c}$ dropping to as low as 3 to $4 \mathrm{MPa}$ to the depth of about $13 \mathrm{~m}$ where refusal was achieved. Although these tests suggested that the soil was clean sand, fines content as high as $30 \%$ was observed in a number of boreholes that were not very far from the project.

At later stages, four additional SPT boreholes were drilled in Lot A-A's tank location. These boreholes indicated that the upper $3 \mathrm{~m}$ of sand was indeed very dense, but the soil then became very loose to medium dense at water level. $N$ values at depths of 3 to $8 \mathrm{~m}$ ranged from 4 to 14 , and then shifted to values in between 11 to 20 to depths of approximately 12 to $13 \mathrm{~m}$. $N$ then exceeded 50 . The average fines content of the 38 samples that were extracted from the four boreholes generally ranged from 16 to $21 \%$ and up to $30 \%$, which was significantly more than the average $5 \%$ that was indicated by the preliminary geotechnical investigation.

Two PMTs were also carried out in Lot A-A. Testing commenced below sea level. Limit pressure, $P_{L M}$, was from less than 100 to about $700 \mathrm{kPa}$. Pressuremeter Moduli, $E_{M}$, varied from less than $1 \mathrm{MPa}$ to approximately $6 \mathrm{MPa}$.

Preliminary studies suggested that mat foundations could not be used for the tanks without the implementation of specific foundation measures. 


\section{Foundation Solution: Dynamic Compaction and Dynamic Surcharging}

Piling and ground improvement were both deemed as possible solutions; however, the former solution was discarded due to the high costs associated with it.

Several ground improvement techniques were considered. Although vibro compaction was the commonly practiced method of ground improvement on Palm Jumeira, the possible presence of silty sand made the applicability of this technique dubious. Stone columns were feasible but appeared to be very costly. Dynamic compaction was considered as both economical and reliable, and the ground improvement works were awarded to a specialist contractor who had proposed this technique.

Soil improvement acceptance criteria for a tank foundation level at level $+2.5 \mathrm{~m} \mathrm{RL}$ were developed as:

- Allowable bearing capacity: $160 \mathrm{kPa}$ with a safety factor of 3

- Differential settlement: 1/750 for a uniformly distributed load of $120 \mathrm{kPa}$.

A study on the available rigs in the region at the time indicated that the maximum pounder lift capacity was limited to 15 tons; thus, in addition to classical dynamic compaction, the specialist contractor decided to implement dynamic surcharging to improve the achievable results at depth.

Dynamic surcharging is the combined effect of static loading and high energy impacts. Its purpose was to create acceleration in the soil under the static loading in such a way to generate a shearing process around the surcharge fill to reduce the load spreading zone of the high strength superficial layer. Furthermore, vibrations and increase of the pore pressure under the tank were to reduce the friction in between the granular soil particles and ultimately result in the collapse and densification of the foundation soil under the influence of dynamic surcharging.

In this technique a surcharge is initially placed over the treatment area, then dynamic compaction is performed. Although granular materials settle under static loads, as dynamic shear modulus has been found to decrease significantly with increasing values of shear strain amplitude (Silver and Seed 1971), it can be expected that introducing vibration will increase the amount of settlement under the surcharge. Furthermore, the rate of consolidation of fine soils is most when the pore water pressure is high, and it is possible to increase the rate of consolidation back to previously high values by inducing pore water pressure through vibration.

Four settlement monitoring plates were installed on the ground surface. One plate was installed in the center of the tank and the others were installed at $120^{\circ}$ angles on a ring whose radius was $17.5 \mathrm{~m}$.

$4 \mathrm{~m}$ of surcharge was then placed at the tank location in the shape of a truncated cone whose top and bottom diameters were respectively $32.2 \mathrm{~m}$ and $44.2 \mathrm{~m}$. It can be calculated that the surcharge volume was approximately $4,700 \mathrm{~m}^{3}$. Assuming that the in-situ unit weight of surcharge was $17 \mathrm{kN} / \mathrm{m}^{3}$, it can be further estimated that its total weight was $80 \mathrm{MN}$. As tank foundation level was at $+2.5 \mathrm{~m} \mathrm{RL}$, an additional overburden weight of $25 \mathrm{MN}$ can be added to total surcharge weight. $4 \mathrm{~m}$ of surcharge and $1.5 \mathrm{~m}$ of overburden generates $93.5 \mathrm{kPa}$ of pressure within the tank's layout, which was equivalent to $78 \%$ of the tank's total load; however, the total surcharge load of $105 \mathrm{MN}$ approximately equated to $90 \%$ of the tank's total load. 


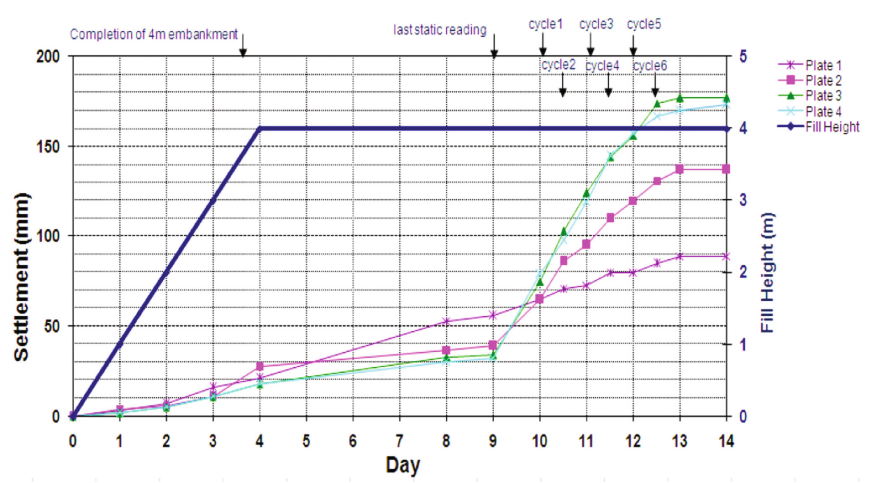

Fig. 6. Ground settlement in tank A-A during static and dynamic surcharging (Hamidi and Varaksin 2015)

Tank A-A settlements during placement of surcharge, static loading and dynamic surcharging are shown in Fig. 6. It can be seen that the plates settled almost prorate with surcharge height. Once placement of surcharge was completed, the preload was left in place for five additional days. By then the settlement rate considerably decreased, and it can be extrapolated that the ground could have additionally settled up to $5 \mathrm{~mm}$ in the long term.

To increase the depth of treatment influence, 26 prints were excavated to the depth of approximately $1 \mathrm{~m}$ on a periphery ring with a diameter of $49.2 \mathrm{~m}$ before applying dynamic surcharging by dropping a 15-ton pounder from $20 \mathrm{~m}$ a total of 30 times in five cycles at the location of each print.

It can be observed in Fig. 6 that dynamic surcharging increased the settlements of Tank A-A by 1.6 to 5.2 times the values of the static settlements. The maximum effect was on the tank's periphery where impact wave amplitudes were greatest. Also, although the maximum differential settlement of the outer monitoring plates was only $7 \mathrm{~mm}$ at the end of static surcharging, maximum differential settlement during dynamic surcharging increased by 4 times to $40 \mathrm{~mm}$, which suggests the possibility of large differential settlements under seismic and vibratory loads in untreated areas of the same ground.

The surcharge was removed and the ground was excavated within a diameter of $41.2 \mathrm{~m}$ to working platform level at $+2.8 \mathrm{~m}$ RL upon completion of dynamic surcharging. The excavation sides sloped outwards in such a way that the top excavation had a diameter of $46 \mathrm{~m}$.

Dynamic compaction was performed on prints located in the center of the tank and on 4 concentric rings around the central print. Each print was additionally excavated by approximately $1 \mathrm{~m}$ to facilitate pounder penetration and to increase the depth of influence. $150 \mathrm{~m}^{3}$ of crushed rock and cobbles were also added to the total of 58 prints in each tank. This amounts to about $2.6 \mathrm{~m}^{3}$ of added rock per print or an equivalent of approximately $0.13 \mathrm{~m}$ of rock thickness per every meter of ground within the treatment zone. This amount of stone was insufficient to efficiently increase the ground strength as was intended and described in Ras Laffan Tank T-6 but was rather used to increase 
soil permeability. Pounder drop height during the first and second phases of compaction was $20 \mathrm{~m}$. A lesser impact energy was used during the ironing phase.

Pounder penetrations and top of crater diameters were measured during the first two phases of dynamic compaction for each print. The average values of these two in phase 1 were respectively $1.7 \mathrm{~m}$ and $5 \mathrm{~m}$. These average figures respectively reduced to $0.4 \mathrm{~m}$ and $2.3 \mathrm{~m}$ in the second phase. It is noted that the pounder's dimension was $1.7 \mathrm{~m}$.

The ground level dropped to $+2.25 \mathrm{~m} \mathrm{RL}$ at the end of dynamic compaction. With consideration of the added stone volume, it can be calculated that the ground had settled $0.68 \mathrm{~m}$ in addition to the settlements induced by dynamic surcharging. Although the magnitude of this settlement is significantly greater than what was measured during dynamic surcharging, it is noted that the purpose of dynamic surcharging was to reduce the settlements of the deep layer that were less impacted by the energy of the 15-ton pounder.

\section{Testing and Verification}

Upon completion of dynamic compaction and leveling of the site, 4 PMTs were carried out in Tank A-A. $P_{L M}$ and $E_{M}$ before and after ground improvement are shown in Fig. 7. It can be observed that most of the improvement has occurred to depths of approximately 8 to $9 \mathrm{~m}$; however, due to the combination of dynamic surcharging and pre-excavated dynamic compaction, $P_{L M}$ increased by $380 \%$ and $70 \%$ respectively at depths of $5 \mathrm{~m}$ and $10 \mathrm{~m}$. Furthermore, minimum $P_{L M}$ after improvement was observed to be greater than $600 \mathrm{kPa}$, which demonstrates that the young hydraulic fill was no longer subject to creep due to self-weight (Menard 1975).

Bearing capacity can be calculated using the equation proposed by Menard (1975). In Tank A-A, the geometric mean of the average of the 4 post ground improvement PMT was 1,684 $\mathrm{kPa}$. Conservatively assuming that the deeper layers also have the same value and that the foundation was on ground level, the allowable bearing capacity can be calculated to be $449 \mathrm{kPa}$, which is considerably greater than the required $160 \mathrm{kPa}$.

Tank settlements were calculated by taking the tank-soil interaction into account and using finite element analysis and three-dimensional modeling. The modeled tank was supported by a $0.5 \mathrm{~m}$ thick concrete raft, which was underlain by a very dense upper layer and a lesser dense bottom layer. The ground in the model was made stiffer on one side by varying the thicknesses of two soil layers to assess differential settlement effects. In this procedure, the thicknesses of the upper and lower sand layers on the left side of the tank were respectively assumed to be $7.5 \mathrm{~m}$ and $3.5 \mathrm{~m}$. On the right side, the upper and lower sand layers were each assumed to be $6.5 \mathrm{~m}$. Young's moduli, $E_{y}$, for the sand layers were calculated from $E_{M}$ (Menard 1975), and assumed to be 57.9 and 22.5 MPa respectively for the upper and lower sand layers.

Finite element analysis suggested that maximum settlement at the center of the tank and minimum settlement at the shell were respectively $21.35 \mathrm{~mm}$ and $10.91 \mathrm{~mm}$. Thus, the differential settlement over the radius length of $17.55 \mathrm{~m}$ was $10.44 \mathrm{~mm}$ or less than $1 / 1,681$, which is substantially less than the allowed value of $1 / 750$. Differential settlement from one side to the other side of the tank was calculated to be $3.13 \mathrm{~mm}$ or less than $1 / 11,200$. 


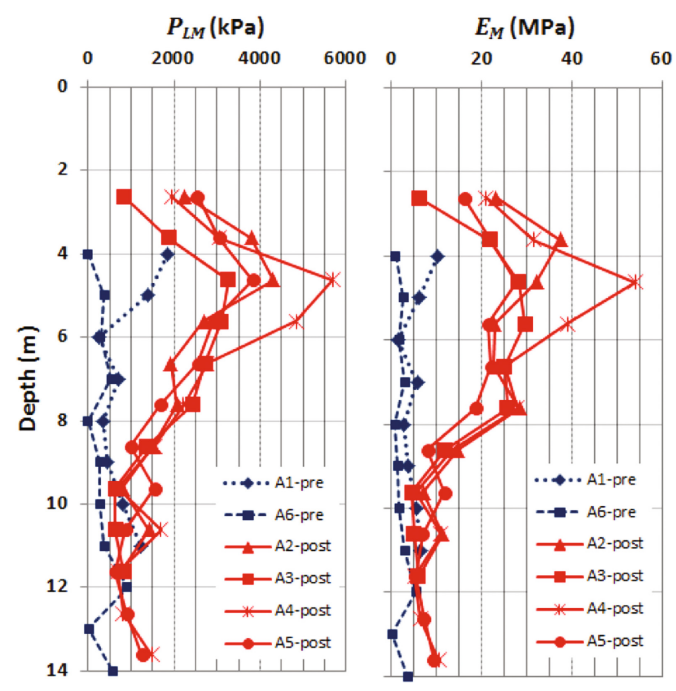

Fig. 7. $P_{L M}$ and $E_{M}$ values before and after ground improvement (Hamidi and Varaksin 2015)

\subsection{Fuel Tanks in Sohar, Oman}

\section{Introduction and Ground Conditions}

Sohar Aluminum Factory is located in Sohar, Oman, and includes a power plant that contains 4 gas turbines, 2 steam turbines, heavy recovery generators, associated buildings, and tanks. Phase one of the power plant includes 2 fuel tanks, and a third tank has been envisaged for the second phase of the plant. The diameters of these steel tanks were approximately $31.25 \mathrm{~m}$, and the required bearing capacity was $200 \mathrm{kPa}$.

Initial geotechnical studies indicated that the ground at the location of the tanks was composed of loose to dense silty sand from the natural ground level at $+5.35 \mathrm{~m} \mathrm{CD}$ (Chart Datum) to $-13 \mathrm{~m} \mathrm{CD}$, where very dense silty sand or sandstone was encountered. Groundwater level was identified at $+1.2 \mathrm{~m} \mathrm{CD}$.

Supplementary PMTs that were later carried out indicated that the upper crust of the ground surface was very dense with $P_{L M}$ of $5 \mathrm{MPa}$. The limit pressure then varied in the range of approximately 1.5 to $2.1 \mathrm{MPa}$.

It was also assessed that the in-situ ground conditions did not satisfy the designer's requirements, and implementation of specific foundation measures was investigated.

\section{Foundation Solution: Dynamic Compaction}

Acceptance criterion that was specified required the allowable bearing capacity of the tank foundations to be $200 \mathrm{kPa}$ with a safety factor of 3 . Tank base levels were defined at $+4.5 \mathrm{~m} \mathrm{CD}$. It is noted that it is the authors' experience that due to their foundation sizes, tanks practically do not fail in bearing and that local shear failure beneath the shell, disruption of tank serviceability or structural damage due to ground deformations are more probable problems that need to be considered. 
Prior to commencement of treatment the working platform level was cut down to elevation $+4.5 \mathrm{~m} \mathrm{CD}$.

A 14.5-ton pounder was used to dynamically compact the ground. Pounder drop height in the first and second phases of ground improvement was $20 \mathrm{~m}$ but was reduced to $10 \mathrm{~m}$ for the ironing phase. 10 and 8 blows were applied per print respectively in phase 1 and phase 2, but only a single blow was applied to each ironing print.

\section{Testing and Verification}

Pressuremeter test results before and after dynamic compaction are shown in Fig. 8. The reference level for depth is at $+4.5 \mathrm{~m} \mathrm{CD}$. It can be observed that even though the strength and deformation parameters at the tank locations was on the denser side of materials, nevertheless $P_{L M}$ and $E_{M}$ respectively improved by approximately 1.6 and 1.9 times in the $4 \mathrm{~m}$ of soil beneath the hard upper crust.

Calculation of allowable bearing capacity using the method of Menard (1975) indicates that the project's criterion has been well satisfied. Also, it can be calculated that settlements within the treated layers of the ground will have reduced to approximately half of the untreated values.
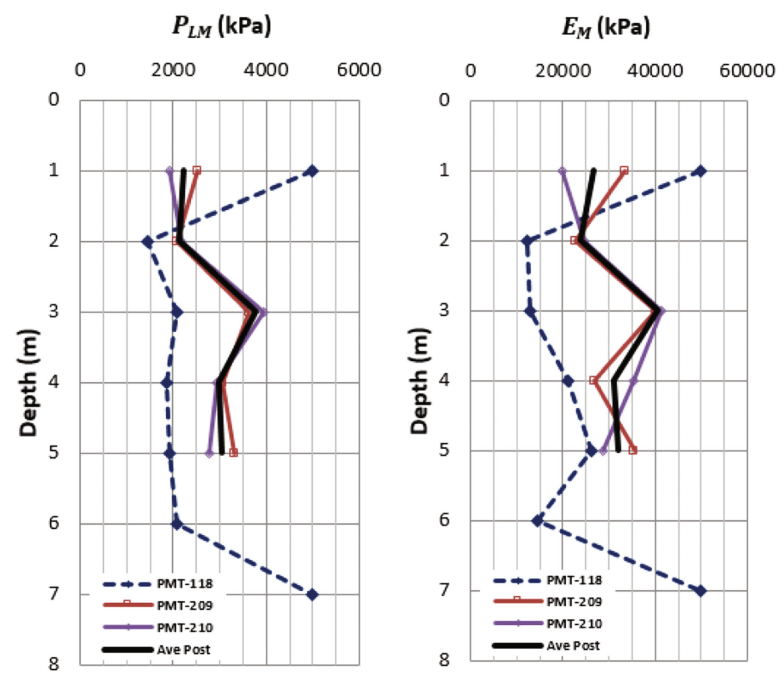

Fig. 8. $P_{L M}$ and $E_{M}$ values before and after ground improvement

\section{Conclusion}

Tanks undergo a combination of uniform settlements, planar tilting and non-planar differential settlements that can undermine the performance and serviceability of tanks, result in damages or ultimately lead to failure. While they are relatively thin, heavily loaded and sensitive structures, international specifications appear to be relatively tolerant to uniform settlements but restrict planar tilting and non-planar deformations more stringently. 
Ground improvement techniques have been used successfully in numerous tank projects throughout the world in general and in the Middle East in particular. Several successful cases of ground improvement by application of dynamic compaction and verification by Menard pressuremeter test for various types of tanks in the region were presented in this paper.

Acknowledgments. The authors would like to express their appreciation to Menard for providing the information used in this paper.

\section{References}

ACI Committee 376: Agenda for Webinars on November 30, December 2 and 16, 2010, p. 23 (2010)

American Concrete Institute: Code Requirements for Design and Construction of Concrete Structures for the Containment of Refrigerated Liquefied Gases, p. 170. ACI, Farmington Hills (2010)

American Petroleum Institute: API Standard 653: Tank Inspection, Repair, Alteration, and Reconstruction, 3rd edn., Washington, D.C., p. 112 (2003)

American Petroleum Institute: API Standard 625: Tank Systems for Refrigerated Liquefied Gas Storage, 1st edn., Washington, D.C., p. 72 (2010)

American Petroleum Institute: API Standard 650: Welded Tanks for Oil Storage, 11th edn., Washington, D.C., p. 445 (2011)

Buschmeier, B., Masse, F., Swift, S., Walker, M.: Full scale instrumented load test for support of oil tanks on deep soft clay deposits in Louisiana using controlled modulus columns. In: International Symposium on Ground Improvement (IS-GI) Brussels 2012, Brussels, pp. 359372 (2012)

Cognon, J.M., Liausu, P., Vialard, R.: Combination of the drains and surcharge method with dynamic compaction. In: 8th European Conference on Soil Mechanics and Foundation Engineering, Helsinki, pp. 219-224. A.A. Balkema, Rotterdam, Netherlands (1983)

Debats, J.M., Scharff, G., Balderas, J., Melentijevic, S.: Ground improvement efficiency and back-analysis of settlements. Ground Improv. 166(3), 138-154 (2013)

D’Orazio, T.B., Duncan, J.M.: Differential settlement in steel tanks. J. Geotech. Eng. ASCE 113(9), 967-983 (1987)

Hamidi, B., Jullienne, D.: The construction and performance of foundation using dynamic compaction and dynamic replacement for an LNG tank in Qatar. In: 16th South East Asian Geotechnical Conference, pp. 523-527 (2007)

Hamidi, B., Masse, F., Racinais, J., Varaksin, S.: The boundary between deep foundations and ground improvement. Geotech. Eng. 169(GE2), 201-213 (2016)

Hamidi, B., Varaksin, S., Nikraz, H.: Application of dynamic surcharging for construction of tanks on reclaimed ground. In: International Conference on Advances in Geotechnical Engineering (ICAGE), Perth, pp. 873-878 (2011)

Hamidi, B., Varaksin, S.: Dynamic compaction and dynamic surcharging at Dubai's Palm Jumeira STP. In: Ground Improvement: Case Histories and New Directions, pp. 309-335. Elsevier, Oxford (2015) 
Hendy, M.S., Muir, I.C.: Experience of dynamic replacement on a $40 \mathrm{~m}$ deep reclamation in Hong Kong. In: Third International Conference on Ground Improvement Geosystems: Ground Improvement Geosystems - Densification and Reinforcement, pp. 76-80. Thomas Telford, London (1997)

Ihm, C.W., Masse, F.: Successful application of Menard vacuum consolidation method to Nakdong river soft clay in Kimhae, South Korea. In: 15th International Conference on Soil Mechanics and Foundation Engineering (ICSMGE), Istanbul (2001)

Marr, W.A., Ramos, J.A., Lambe, T.W.: Criteria for settlement of tanks. J. Geotech. Geoenviron. Eng. 108(GT8), 1017-1039 (1982). ASCE

Menard, L.: The Menard Pressuremeter, Sols Soils No. 26 (1975)

Mobil: Chapter 6 - Foundation Design. Mobil Engineering Guide: EGS 262-90. Mobil (1990)

Silver, M.L., Seed, H.B.: Deformation characteristics of sands under cyclic loading. J. Soil Mech. Found. Div. 9(SM8), 1081-1098 (1971). ASCE 